\title{
SUATU TINJAUAN TENTANG PERALATAN KEDOKTERAN NUKLIR DAN MASALAH PEMELIHARAANNYA
}

\author{
Rill Isaris \\ Pusat Penelitian dan Pengembangan Teknologi Maju BATAN \\ Jl. Babarsari Kotak Pos 1008, Yogyakarta 55010
}

\begin{abstract}
ABSTRAK
SUATU TINJAUAN TENTANG PERALATAN KEDOKTERAN NUKLIR DAN MASALAH PEMELIHARAANNYA. Peralatan Kedokteran Nuklir (PKN) tergolong rumit serta memerlukan perhatian untuk mempertahankan agar tetap berada dalam kondisi operasional yang baik, dan terdapat berbagai kendala dalam melaksanakan perawatannya terutama di negara sedang berkembang. Beberapa kendala yang terdeteksi adalah akibat gangguan kondisi lingkungan, tidak adanya dukungan engineer dari pabrik alat, tidak memadai staf lokal terlatih, kesulitan mendapatkan spareparts, komplikasi administratif, masalah dana, dsb-nya. Dalam makalah ini dikemukakan dan dibahas secara ringkas faktor tersebut berdasarkan pengalaman melaksanakan perawatan peralatan kedokteran nuklir di berbagai rumahsakit, selanjutnya dikemukakan catatan perawatan peralatan Gamma Camera dan kondisi saat ini sebagai ilustrasi. Juga dikemukakan upaya yang harus dilakukan dalam suatu sistem perawatan komprehensif terutama untuk peralatan kedokteran nuklir yang masih operasional dan atau yang baru. Dikemukakan pula organisasi dan manajemen sistem perawatan maju yang meliputi komponen : 1) kesehatan laboratorium, 2) pemeliharaan preventif dan 3) pemeliharaan korektif untuk dapat diadopsi. Berdasarkan review pada pengalaman negara-negara sedang berkembang, mengembangkan kemampuan sendiri dalam melaksanakan perawatan alat adalah sangat penting, karena dengan menggunakan sistem kontrak akan sangat mahal dan selalu tergantung pihak lain. Utuk meningkatkan keandalan dan memperbaiki kualitas PKN perlu dilakukan program kendali kualitas secara rutin di rumahsakit.
\end{abstract}

\begin{abstract}
A REVIEW TO NUCLEAR MEDICINE EQUIPMENTS AND ITS MAINTENANCE PROBLEMS. Nuclear Medicine Instruments (NMI) are rather sophisticated and attention must be given to maintain it in good working condition, numerous difficulties are encountered in performing the maintenance in developing countries. Many factors contribute to these difficulties, i.e.: severe environmental conditions, absence of factory-based service engineers, lack of local technical staff, shortage of spare parts, administrative complication, financial problems and others. This paper describes these factors based on the experiences gained in carrying-out the maintenance of nuclear medicine instruments in some hospitals since 1990, then maintenance records and condition of gamma cameras in hospitals are also shown as an illustration. Moreover, the efforts should be done in a comprehensive maintenance system for nuclear medicine equipments in operating or the new one are also given. The maintenance system and its management are also presented which consist of : 1) laboratory hygiene ,2) preventive maintenance and 3) corrective maintenance \& repair. The development of a "self reliance" in maintenance of equipments in developing countries is an essential choose, because of the maintenance-contract is very costly and always depend on the other party. In order to improve the reliability and quality of the NMI in hospitals, a routine quality control program is recommended.
\end{abstract}

\section{PENDAHULUAN}

$\mathrm{K}$ elancaran pelayanan diagnostik dan atau terapi di rumah sakit sangat tergantung pada kemampuan mempertahankan seluruh peralatan dalam kondisi operasional yang sempurna, dan mengembalikan peralatan pada kondisi unjuk-kerja yang optimal untuk menjamin hasil diagnosis dan perlakuan yang berkualitas tinggi kepada pasien dan staff rumahsakit. Hal tersebut bisa tercapai jika program perawatan dapat direncanakan dan 
dilaksanakan secara baik. Peralatan Kedokteran Nuklir (PKN) seperti halnya scientific instruments yang lain memiliki sistem yang kompleks, mulai dari detektor nuklir, sistem deteksi dan konversi radiasi, sistem akuisisi dan pengolah data (elektronik), sistem manipulasi \& komputasi dan penampil data, serta sistem mekanik \& elektrik, mengharuskan operator dan engineer/physician yang menangani peralatan harus memiliki latar belakang pengetahuan tentang instrumentasi nuklir. Dari laporan National Counterpart pada IAEA Meeting ${ }^{(1)}$, dikemukakan perawatan PKN di negara sedang berkembang menemui banyak kesulitan oleh berbagai faktor yang antara lain adalah : 1) tidak memadai staf teknis terlatih dan medical physicist, 2) buruknya kondisi lingkungan instrumen, 3) tidak tersedia service contract memadai dan kelangkaan replace-parts, 4) komplikasi administrasi, 5) problem dana, dll. Tingkat kecanggihan sistem PKN yang terbentuk karena multi-system dan komponen elektronik Hi-reliability serta komputerisasi Sistem juga menambah kendala pelaksanaan program perawatan jika proteksi terhadap PKN dan peningkatan kemampuan SDM tidak dipenuhi. Menurut Rill Isaris ${ }^{(2)}$ sering terjadi kerusakan alat dimana sumber kerusakan bukan dari kualitas atau kesalahan komponen, tetapi adalah dari faktor luar seperti : 1) Buruknya kualitas Laboratory Environtment and Power Conditioning (Instrument Protection Devices), 2) Tidak dilakukan perawatan preventif dan 3) kesalahan operasional (human error). Dari laporan program pemeliharaan instrumentasi nuklir IAEA $^{(3)}$ disimpulkan kegagalan memperbaiki instrumentasi nuklir di kawasan Asia adalah karena factor sukucadang, hilangnya dokumen teknis, tidak bisa dilakukan service di tempat, ada bagian yang harus dimodifikasi dan tidak memadai ketrampilan untuk melakukan refurbishment dan modifikasi. Dari statistik data observasi terhadap penyebab kerusakan pada komponen elektronik PKN menunjukkan bahwa impulse-spike menyumbang 50\% malfunction pada alat. Oleh karena itu setelah selesai proses pengadaan peralatan yang diikuti dengan commissioning-tests dan acceptance tests, maka dimulailah program perawatan alat (preventive-maintenance) secara komprehensif termasuk pelatihan secara rutin staf teknis serta pelaksanaan program uji kualitas (quality control) secara rutin oleh operator/technologist. Kedua hal ini sangat penting dan saling berkait untuk mendapatkan hasil pengkuran yang berkualitas tinggi seperti dilaporkan oleh Rill Isaris $^{(4)}$ dalam observasinya terhadap Peralatan Gamma Camera/ SPECT serta faktor-faktor yang menimbulkan cacat dan non-uniformity hasil citra (image) replika organ tubuh. Masalah perawatan dan pengadaan alat baru belum banyak berubah sampai awal tahun 2000-an , mungkin masih disebabkan krisis ekonomi dunia.

Secara global, Sistem Perawatan (Maintenance System) ditunjukkan dalam Gambar 1. Dalam sistem pemeliharaan maju untuk peralatan semacam Instrumentasi Kedokteran Nuklir yang memerlukan nilai availability \& maintainabilitty yang tinggi, maka "Perawatan Terencana" lah yang harus dipilih yang terdiri dari 3 komponen sbb :

o Laboratory hygiene (Kebersihan

Laboratorium, Pengkondisian Lingkungan Alat, dan Pengkondisian Power Supply )

o Preventive Maintenance (Commissioning \& Acceptance tests, Reference \& Routine Tests).

o Corrective Miantenance (Repair, modification, overhault).

\section{Pemeliharaan Preventif}

Pemeliharaan preventif adalah setiap usaha untuk mengembalikan peralatan kepada kondisi/spesifikasi semula, melalui berbagai pengecekan, pengukuran, kalibrasi dan penggantian jika perlu. Pemeliharaan preventif untuk industri nuklir dilaksanakan 
pada kategori yang direkomendasi IAEA ${ }^{(5)}$ sbb :

a. item-item yang dispesifikasi oleh perancang sistem

b. item-item untuk keperluan pemenuhan persyaratan asuransi

c. item-item yang dispesifikasi sesuai kebutuhan persyaratan dalam peraturan

d. item-item yang ditetapkan oleh manajemen berdasarkan hasil pengkajian keselamatan, pengalaman operasi, dan lain sebagainya.

Cacat-cacat yang terdeteksi dalam pemeliharaan preventif hendaklah diikuti dengan perbaikan yang tepat atau penggantian melalui pemeliharaan korektif. Data-data yang terdeteksi tentang kegagalan \& kelainan harus diinventaris dan dibuat laporannya untuk kemudian dianalisis untuk menetapkan tindakan selanjutnya yang harus dilakukan.

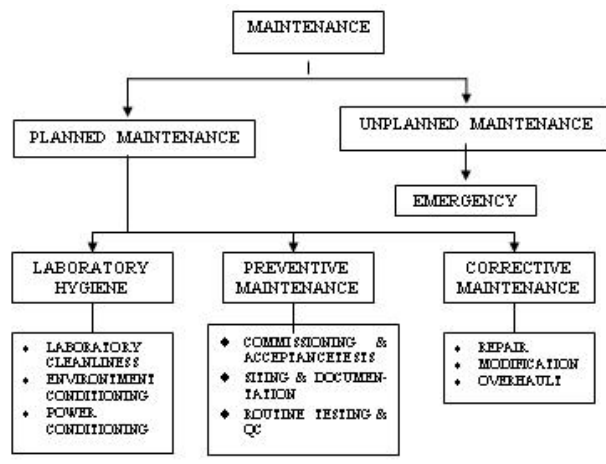

Gambar 1. Sistem dan Bagian Kegiatan Pemeliharaan (Maintenance)

Cacat-cacat yang terdeteksi dalam pemeliharaan preventif hendaklah diikuti dengan perbaikan yang tepat atau penggantian melalui pemeliharaan korektif. Data-data yang terdeteksi tentang kegagalan \& kelainan harus diinventaris dan dibuat laporannya untuk kemudian dianalisis untuk menetapkan tindakan selanjutnya yang harus dilakukan.

\section{Pemeliharaan Korektif}

Pemeliharaan korektif dilakukan setelah dipastikan terdapat bagian atau komponen alat yang mengalami kerusakan. Untuk mampu melaksanakan pemeliharaan korektif PKN seperti juga pada pemeliharaan preventif, beberapa persyaratan harus dipenuhi a.l.:

1. Instrument expert and technician yang terlatih dan memiliki latar belakang instrumentasi nuklir dan proteksi radiasi.

2. Peralatan untuk troubleshooting and repair (Oscilloscope, Function Generator, Tool Kits, Logic Analyzer, Soldering \& De-soldering, TecDoc, dll.)

3. Jalur pengadaan spare/replace-parts

4. Alokasi dana yang cukup ( $10-20 \%$ harga alat)

Setiap selesai melaksanakan pemeliharaan korektif, harus dilakukan kalibrasi pada karakteristik utama alat.

Hubungan antara Maintenance-cost terhadap Reliability (keandalan) berbagai kelas Sistem/alat/instrument kaitannya dengan kegiatan pemeliharaan preventif (PP) dan pemeliharaan korektif (PK) dapat ditunjukkan pada Gambar 2.

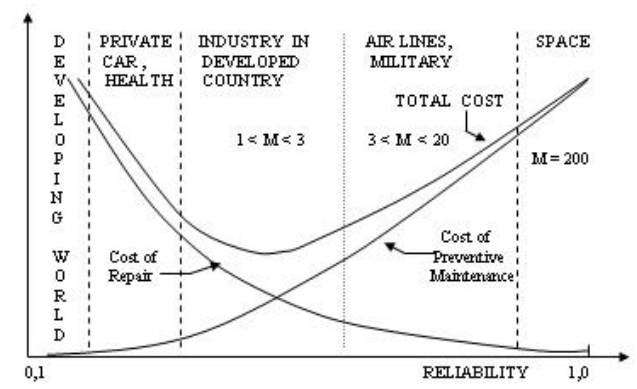

Gambar 2. Korelasi Biaya Pemeliharaan vs Keandalan Sistem kaitan dengan Pemeliharaan Preventif dan Pemeliharaan Korektif.

Dapat dikatakan bahwa Pemeliharaan Preventif adalah esensial terutama untuk peralatan yang strategis / yang memiliki nilai ekonomi yang tinggi adalah dalam rangka :

1. Untuk memaksimumkan "Mean Time Between Failure“ (MTBF) 
2. Untuk meminimumkan "Un-availability of Equipment"

\section{PERALATAN KEDOKTERAN NUKLIR}

Sampai 2002 terdapat 18 Unit Kedokteran Nuklir di Indonesia dengan sekitar 32 unit Gamma Camera/SPECT yang terdapat di 15 UKN dan peralatan lainnya baik yang in vitro maupun in-vivo. Menurut Iyos R.Subki ${ }^{(6)}$ kedokteran nuklir di negara sedang berkembang kurang cepat kemajuannya karena masalah budget dan karekter multidisiplin yang harus dimiliki kedokteran nuklir tsb.

Secara umum Instrumentasi Kedokteran Nuklir yang utama terbagi kedalam 9 jenis seperti dalam Tabel 1 berikut :

Tabel 1 Instrumentasi Kedokteran Nuklir Utama

\begin{tabular}{|c|l|l|}
\hline No. & \multicolumn{1}{|c|}{ Nama Alat } & \multicolumn{1}{c|}{ Keterangan } \\
\hline 1. & Radionuclide Dose Calibrator & Pengukur Dosis Radiasi (Ci, Bq) \\
\hline 2. & Nuclear Counting System & In-Vitro, Gamma Radiation, RIA \\
\hline 3. & $\begin{array}{l}\text { Single \& Multi Probes Nuclear } \\
\text { Counting System }\end{array}$ & $\begin{array}{l}\text { In-Vivo, Gamma Radiation } \\
\text { Thyroid Up Take, Renograph }\end{array}$ \\
\hline 4. & Rectilinear Scanners & In-vivo \\
\hline 5. & Scintillation Gamma Camera & Conventional, Analog System \\
\hline 6. & Camera Computer System & Digital System \\
\hline 7. & $\begin{array}{l}\text { Single Photon Computed Tomography } \\
\text { (SPECT) }\end{array}$ & Tomography, Rotating \\
\hline 8. & Positron Emmission Tomography (PET) & Tomography, Rotating, physiological studies \\
\hline
\end{tabular}

Instrumentasi Nuklir menggunakan berbagai sophisticated instruments, antara lain :

Detektor Nuklir NaI (Tl) sebagai sensor radiasi

$>$ Sistem elektronik analog yang sensistif

$>$ Extended digital circuits

$>$ Micro \& Nano-processor

$>$ Interfaces to Computer

$>$ Complete computer system

Sehingga untuk memahami fungsi dan cara kerja instrumentasi berbasis nuklir, perlu dipelajari tentang sumber \& sifat radiasi, proteksi radiasi, elektronika nuklir, dll.

Perkembangan terkini Peralatan Kedokteran Nuklir telah dilaporkan oleh Valentin Fidler $^{(7)}$ yang antara lain menyebutkan penggunaan bahan deteksi baru (detector) dengan karakteristik fisis (stopping power, energy resolution, fragility, decay time, light output and density) yang jauh lebih baik dibanding $\mathrm{NaI}$, sehingga diproyeksi akan menggantikan $\mathrm{NaI}$ dan dikonstruksi dalam ratusan kristal kecil sehingga mampu meningkatkan sensitivitas dan spesifitas studi klinis.

\section{MANAJEMEN PEMELIHARAAN/ PERAWATAN}

Kebijaksanaan preservasi peralatan kedokteran perlu ditetapkan melalui supervisi Sistem Manajemen pada kegiatan pemeliharaan, untuk memberikan hasil-balik yang efisien terhadap investasi dan pelayanan terbaik dan terjamin mutunya terhadap pasien. Pengabaian terhadap program pemeliharaan alat akan menimbulkan biaya ekonomi yang berkepanjangan dan mahal (expensive long-run cost of economy).

Dari laporan survei $\operatorname{IAEA}^{(8)}$ dikemukakan berbagai faktor yang menyebabkan peralatan laboratorium (termasuk alat kedokteran nuklir) di negara sedang berkembang lebih sering menemui kegagalan/kerusakan, yaitu : 


\section{Faktor Manajemen :}

1. Manajemen pengadaan kurang mempertimbangkan dan memperhatikan program

2. pemeliharaan dan Quality Control.

3. Kurang apresiasi terhadap pemeliharaan (budget, proteksi alat, prioritas)

4. Kurang memadai training staf teknis di bidang peralatan dan pemeliharaan

Faktor Teknis :

1. Tidak memadai dukungan/support dari Representative agent of manufacturer.

2. Program Pemeliharaan Preventif tidak memadai

3. Kondisi Lingkungan laboratorium tidak mendukung (kelembaban udara/RH $>70 \%$, temperatur $>32^{\circ} \mathrm{C}$, degradasi temperatur yang ekstrim, berdebu), yang dapat merusak komponen elektronik, timbul bad-contact, High Voltage Power Supply damaged, dll.).

4. Tidak terlindungi terhadap Sumber Daya Listrik (Mains) yang berkualitas

5. rendah (Sags, Surges, Voltage Fluctuation, Transient/Impulse-Spike, Noise, Power Interrupt , dll. ).

Selanjutnya dari laporan Rill Isaris ${ }^{(9)}$, dikemukakan problem yang ditemukan dalam melaksanakan perbaikan peralatan Gamma Camera di rumahsakit adalah :

- Kesulitan mendapatkan quick-service untuk reparasi, dan pengadaan replace-parts ( hal ini meningkatkan Mean Time To Repair = MTTR )

- Harga komponen/replaceparts yang sangat mahal

- Sebagian pabrik Alat tidak memenuhi komitmen-nya untuk melakukan alih teknologi terutama untuk pemeliharaan.

Sementara hasil survei IAEA (10) terhadap 13 unit Gamma Camera di 7 negara Asia, menunjukkan terjadi unavailability sebesar $26 \% \quad(\sim 14$ minggu/tahun).

Didalam Sistem Pemeliharaan Terencana (Planned Maintenance System) segala sesuatu yang berkait dengan kepentingan pemeliharaan harus dimulai sejak rencana pengadaan barang, yang urutannya ditunjukkan dalam Gambar 3.

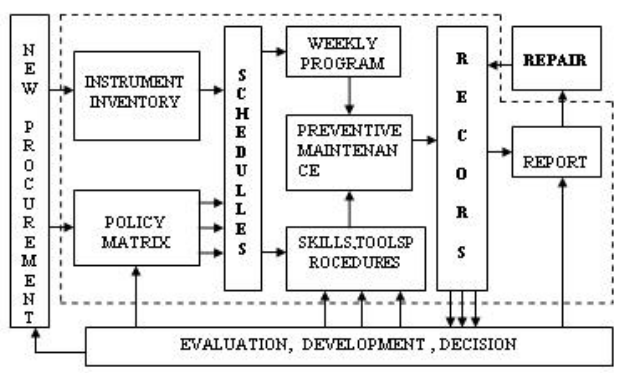

Gambar 3. Diagram Blok Sistem Pemeliharaan Terencana (Planned Maintenance System)

\section{Instrument inventory memuat segala} data tentang alat, yaitu :

- Instrument manuals (service, operating \& drawings)

- Nama pabril alat \& representative agent

- Instrument Environtment \& Power Conditioning

- Normal \& Critical spareparts

- Prosedur pemeliharaan PM

- Schedulle / Permintaan kerja

- Rencana Pemeliharaan

\section{Policy Matrix memuat Program} Perangkat Lunak dengan file-file sbb :

- File prosedur

- File komponen

- File tindakan ( berkala \& tak berkala )

- File tindakan yang tertunda

- File riwayat peralatan \& lokasi

- File hasil records ( informasi )

\section{Evaluasi rencana pemeliharaan}

Dilaksanakan dengan selalu memperhatikan hasil/informasi yang telah diperoleh, yaitu menggunakan :

- File Riwayat Rencana Pemeliharaan

- Pengalaman operasi eksternal

- Pengalaman operasi internal

- Pengalaman industri (manufacturer technical bulletin) 


\section{Dokumentasi}

Dokumen hasil pemeliharaan dan in-service inspection yang telah diperiksa dan di-approved oleh Manajer Pemeliharaan didokumentasikan dalam bentuk file dan disimpan secara baik. Hasil pelaksanaan pemeliharaan preventif dan perbaikan didokumentasikan dalam bentuk file kedalam Sistem Komputer.

\section{Manajemen Sukucadang (spareparts)}

Dilaksanakan dalam sistem komputerisasi sehingga secara cepat dapat diketahui stock suku cadang, daftar pemasukkan dan pengeluaran sukucadang, minimum stock of spareparts.

\section{Penjadwalan}

Dibuat berdasarkan kondisi akhir peralatan (riwayat perbaikan, umur alat) dan tenaga teknis tersedia.

\section{Pengawasan}

Pengawasan pelaksanaan kegiatan pemeliharaan dilakukan oleh seorang Instrument expert secara langsung atau tidak langsung. Dalam melakukan kegiatan in-service inspection, digunakan daftar yang sudah baku yang memuat keterangan a.l. :

a. Jenis inspeksi

b. Interval inspeksi

c. Lingkup inspeksi

d. Kondisi operasi Alat

e. Dokumen dan Alat bantu diperlukan

f. Prosedur

g. Waktu inpeksi yang di-approved oleh Inspektur

Didalam pemeliharaan preventif, seluruh prosedur terjadwal harus dilaksanakan dan mencatat hasilnya untuk menentukan kebijaksanaan manajemen pemeliharaan secara keseluruhan, termasuk untuk pertimbangan :

o Pengadaan peralatan baru dan peralatan bantu reparasi

o Pengaturan kembali penjadwalan (policy matrix)

o Penyediaan sukucadang o Program pelatihan personnel (training)

Hal lain yang juga perlu diperhatikan untuk menjaga kondisi prima operasional alat adalah pelaksanaan quality control tests pada alat. Untuk melakukan QC-tests pada berbagai peralatan kedokteran nuklir dapat diacu pada dokumen teknis IAEA $^{(11)}$, dimana untuk Gamma Camera misalnya terdapat 13 item yang harus dilakukan (Uniformity, Intrinsic uniformity, System uniformity, intrinsic resolution, system resolution, intrinsic linearity, collimator sensitivity, count rate performance, COR, energy correction, uniformity correction, SPECT Phantom, whole body). Pada umumnya uniformity-test dan resolution harus dilakukan setiap hari dan COR test pada SPECT minimal sekali seminggu harus dilakukan. Pada umumnya kendala yang dihadapi rumahsakit dalam melaksanakan QC-tests adalah 1) rumitnya dan detail prosedur QC yang memakan waktu tidak tersedianya perlengkapan untuk QC-phantom dan tidak memadainya personel yang terlatih. Survei terhadap 61 Unit Kedokteran Nuklir di Australia (12) menunjukkan tidak seluruh rumahsakit memiliki QC-phantom secara lengkap seperti ditunjukkan sbb:

Flood tank/Co-57 sheet : $67 \%$

Flood tank : 56\%

Co-57 sheet source : : $33 \%$

Quadrant Bar Phantom : $85 \%$

PLES phantom : $\quad 7 \%$

NEMA Slit Phantom : $\quad 30 \%$

SPECT Phantom : $\quad 31 \%$

Jumlah Gamma Camera dan SPECT yang ada di rumahsakit di Indonesia pada saat ini sangat kecil terhadap jumlah penduduk apalagi sebagian sedang tidak berfungsi. Dari laporan Forum IAEA Meeting $^{(1)}$ 1996, jumlah Gamma Camera/SPECT, PDB, Jumlah populasi dan jumlah tenaga dokter di beberapa negara Asia dan Oceania ditunjukkan dalam Tabel 2. 
Tabel 2. Jumlah Kamera Gamma , Besarnya Product Domestic Bruto(PDB), Populasi dan Jumlah Dokter di Asia \& Oceania

\begin{tabular}{|c|c|c|c|c|c|c|c|}
\hline \multirow{2}{*}{ No. } & \multirow{2}{*}{$\begin{array}{c}\text { Negara } \\
\text { Anggota IAEA }\end{array}$} & \multicolumn{2}{|c|}{$\begin{array}{c}\text { Jumlah Gamma } \\
\text { Camera }\end{array}$} & \multicolumn{2}{|c|}{$\begin{array}{l}\text { PDB (milyard } \\
\text { US.\$) }\end{array}$} & \multirow{2}{*}{$\begin{array}{c}\text { Populasi } \\
\text { (juta) } \\
1996\end{array}$} & \multirow{2}{*}{$\begin{array}{c}\text { Jumlah dokter } \\
1996\end{array}$} \\
\hline & & 1996 & $\begin{array}{c}\text { Prediksi } \\
2002\end{array}$ & 1996 & 2002 & & \\
\hline 1. & Australia & 147 & 159 & 254.4 & & 18.8 & 37.105 \\
\hline 2. & Bangladesh & 5 & 6 & 22.5 & & 130 & 15.600 \\
\hline 3. & China & 500 & 530 & 502 & & 1.300 & 998.707 \\
\hline 4. & India & 141 & 152 & 302.9 & & 987 & 310.225 \\
\hline 5. & Indonesia & 32 & 32 & 118.7 & 150 & $200\left(220^{*}\right)$ & $20.198\left(21.600^{*}\right)$ \\
\hline 6. & Korea Selatan & 332 & 350 & 335.9 & & 50 & 38.557 \\
\hline 7. & Pakistan & 58 & 62 & 52.6 & & 150 & 37.767 \\
\hline 8. & Philliphine & 38 & 41 & 49.9 & & 75 & 10.010 \\
\hline 9. & Singapore & 9 & 12 & 147.6 & & 3.5 & 1.206 \\
\hline 10. & Sri Lanka & 10 & 11 & 7.9 & & 19.5 & 2.015 \\
\hline 11. & Thailand & 13 & 15 & 115.7 & & 61.5 & 9.225 \\
\hline 12. & Vietnam & 10 & 12 & 16.7 & & 77.6 & 20.974 \\
\hline 13. & Jepang & 500 & 550 & 2.115 .2 & & 130 & 202.201 \\
\hline
\end{tabular}

Sumber : Y.Xie- IAEA : QC of Multi Head SPECT Workshops, Seoul Korea 1996 dan dari World Atlas CD. The Software Toolworks, Inc (diolah), dan asumsi perkembangan 10\% / decade.

Catatan : ${ }^{*}=$ perkiraan tahun 2002 untuk Indonesia.

Tabel 3. Unit Kedokteran Nuklir di Indonesia dan Pelayan Utama dilakukan , keadaan tahun 2002

\begin{tabular}{|c|l|c|c|c|c|c|c|}
\hline & & & & & & \multicolumn{2}{|c|}{$\begin{array}{c}\text { Jumlah } \\
\text { Kamera .Gamma } \\
\text { operasional }\end{array}$} \\
\cline { 5 - 7 } & & Nama Rumahsakit & Kota & In Vivo & In Vitro & Terapi & \multicolumn{2}{|c|}{$\begin{array}{c}\text { Planar } \\
\text { No. }\end{array}$} & & & & & + & 2 & 3 \\
\hline 1. & RSUD Hasan Sadikin & Bandung & + & + & + & 1 & 2 \\
2. & RSUP Cipto M.K. & Jakartra & + & + & + & 1 & 1 \\
3. & RSPAD Gatot S. & Jakarta & + & + & + & 1 & 1 \\
4. & RSUP Fatmawati & Jakarta & + & + & + & 2 & 2 \\
5. & RSJ Harapan Kita & Jakarta & + & - & - & 0 & 0 \\
6. & RS.Kanker Dharmais & Jakarta & + & - & - & 1 & 0 \\
7. & RSPP Pertamina & Jakarta & + & + & + & 1 & 2 \\
8. & RSUD Dr.Soetomo & Surabaya & + & - & + & 1 & 1 \\
9. & RSU Dr.Syaiful A. & Malang & + & - & - & 0 & 1 \\
10. & RSU Dr. Kariadi & Semarang & + & - & - & 1 & 1 \\
11. & RSU Dr.Sardjito & Jogyakarta & + & - & - & 1 & 1 \\
12. & RSU Dr.M.Djamil & Padang & + & + & - & 1 & 1 \\
13. & RSU Dr.Wahidin S.H & U.Pandang & + & - & - & 0 & 1 \\
14. & RSU Adam Malik & Medan & & + & + & 0 & 1 \\
15. & RS MMC & Jakarta & + & - & - & 0 & 1 \\
\hline
\end{tabular}

Sementara itu dari 32 Gamma Camera yang ada di rumahsakit tahun 1996, kondisinya 7 rusak dan sampai tahun 2002 tidak terjadi penambahan. Dari 18 rumah sakit yang ada Unit Kedokteran Nuklir, 15 diantaranya memiliki alat Gamma Camera/ SPECT yang menurut laporan Rill Isaris ${ }^{(13)}$ distribusi dan tipe Camera ditunjuk- kan pada Gambar 3. Sementara Tabel 3 memperlihat- kan 15 Unit Kedokteran Nuklir 
berikut pelayanan utama kedokteran nuklir yang diberikan.

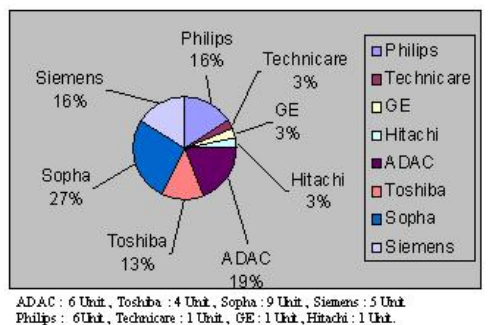

Gambar 4. Distribusi dan tipe Gamma Camera/SPECT di 15 Unit Kedokteran Nuklir di Indonesia

\section{KERJASAMA}

Dalam kondisi perekonomian yang sulit saat ini dan sangat terbatasnya devisa bagi negara sedang berkembang untuk pengadaan peralatan baru khususnya di bidang kedokteran nuklir, maka kebijaksanaan melaksanakan program pemeliharaan alat adalah pilihan yang bijaksana (Prevention is better than cure). Untuk itu perlu dimiliki kemampuan melaksanakan program pemeliharaan (preventif dan reparasi) secara terencana dan berkesinambungan. Sejak 1985 BATAN telah mengembangkan program Pemeliharaan Instrumentasi Nuklir, dan sejak 1989 para engineer dan teknisi BATAN telah terlibat dalam kegiatan membantu berbagai rumahsakit dalam memelihara dan memperbaiki kerusakan pada berbagai peralatan kedokteran nuklir khususnya Gamma Camera. Alih teknologi teknik pemeliharaan alat juga telah dilakukan melalui program pelatihan tenaga teknis rumahsakit, baik selama technical-visit ke rumahsakit maupun dalam Diklat di Instalasi BATAN.

Dengan semakin meningkatnya kebutuhan masyarakat terhadap pelayanan yang terbaik dari rumahsakit, maka diperlukan peralatan yang harus selalu dalam kondisi operasional yang baik, terjamin kualitas hasil pemeriksaan, dan tenaga teknis pemeliharaan yang handal. Perubahan paradigma yang mengharuskan rumahsakit mampu berfungsi sebagai suatu unit swadana akan mendorong pihak Manajemen untuk menciptakan kondisi pelayanan yang optimum pada seluruh jajarannya.

Dalam era baru ini linkage antara Lembaga Litbang dan kebutuhan industri biasanya ditempuh melalui kerjasama "tripartite“, yaitu : 1) Lembaga Litbang, 2) Resources based, dan 3) Enterprises yang memberikan capital injection.

Rumahsakit dapat diumpamakan sebagai suatu resources based dan sebagai suatu proyek industri yang harus ekonomis. Upaya untuk memperpanjang umur teknis peralatan kedokteran nuklir atau peralatan medis lain yang ada saat ini adalah sangat essensial. Dapat dibayangkan berapa sebenarnya jumlah dana yang hilang (lost-value) dengan tidak bisa beroperasinya sebuah Gamma Camera misalnya di rumah sakit.

Kerjasama kemitraan antara rumahsakit dan BATAN dalam hal diseminasi dan pendayagunaan hasil rekayasa dan inovasi teknologi peralatan kedokteran nuklir dan biomedik serta pelayanan jasa maintenance peralatan kedokteran nuklir khususnya merupakan suatu peluang dan tantangan yang seyogyanya dapat menghasilkan "win-win solution" bagi kepentingan kedua belah pihak.

Sementara peran pihak III sebagai Wirausahawan / pendukung dana sangat diperlukan dalam memperlancar kerjasama ini.

BATAN telah memiliki fasilitas dan kemampuan sbb. yang dapat didayagunakan :

> Laboratorium elektronik dan mekanik dengan peralatan untuk pemeliharaan yang lengkap di berbagai Fasilitas (Serpong, Yogyakarta, Bandung)

> Pengalaman melaksanakan pemeliharaan dan perbaikan peralatan kedokteran nuklir, khususnya Alat Gamma Camera, oleh engineer dan teknisi. 
Kerjasama Program Pemeliharaan Instrumentasi Nuklir dengan bantuan International (IAEA)

Hubungan dengan tenaga ahli dari luar negeri, dalam hal konsultasi, training dan informasi mendapatkan sukucadang.

Data-data seluruh Gamma Camera di RSUP serta riwayat kerusakan dan tindak reparasi yang dilakukan Prosedur
Preventif Maintenance berbagai Peralatan Kedokteran Nuklir

Lembaga Pusdiklat untuk pelatihan Pemeliharaan dan Quality Control Instrumentasi Kedokteran Nuklir.

Tabel 4 menunjukkan Contoh jenis kerusakan dan Perbaikan yang telah dilakukan oleh Tim BATAN di RSUP. Dr. Sardjito dan RSUD Dr.Soetomo.

Tabel 4. Contoh Kerusakan dan Perbaikan SPECT

1. RSUP. Dr. Sardjito

\begin{tabular}{|c|c|c|}
\hline Tahun & Jenis Kerusakan & Keterangan Perbaikan \\
\hline 2000 & - Uniformity jelek & - Kalibrasi Flood \\
\hline 2001 & $\begin{array}{l}\text {-PDP tidak bisa mengolah data } \\
\text {-CPU Komputer PC/AT tak bisa berfungsi }\end{array}$ & $\begin{array}{l}\text { - Ganti Memory Board CPU } \\
\text { - Ganti Hardisk \& Set Up }\end{array}$ \\
\hline 2002 & $\begin{array}{l}\text { - Spektrum energi tidak terkalibrasi } \\
\text { - Uniformity diluar nilai batas }\end{array}$ & $\begin{array}{l}\text { - Ganti socket HV dan bersihkan } \\
\text { socket PMT } \\
\text { - Kalibrasi Flood }\end{array}$ \\
\hline 2003 & $\begin{array}{l}\text { - Translasi Gantry macet } \\
\text { - Tidak bisa Akuisisi Data }\end{array}$ & $\begin{array}{l}\text { - Ganti gigi/gear } \\
\text { - Reparasi Power Supply +12V }\end{array}$ \\
\hline 2004 & $\begin{array}{l}\text { - Spektrum energi jelek/ turun } \\
\text { - Tidak bias Akuisisi Data } \\
\text { - Rotasi Gantry macet }\end{array}$ & $\begin{array}{l}\text { - Bersihkan socket PMT dan HV } \\
\text { - Ganti kabel utama pada Gantry } \\
\text { - Perbaiki Power Supply kontrol } \\
\text { motor pada relay. }\end{array}$ \\
\hline 2005 & $\begin{array}{l}\text { - Total Body Scan tidak bisa } \\
\text { - Uniformity jelek } \\
\text { - Terjadi "hot spot" pada image }\end{array}$ & $\begin{array}{l}\text { - Ganti Board Matrox PC/AT } \\
\text { - Perlu mengganti PMT yang rusak }\end{array}$ \\
\hline
\end{tabular}

2. RSUP Dr. Soetomo

\begin{tabular}{|c|c|c|}
\hline 1993 & -Komputer PC/AT tidak bisa booting & -Komputer kena virus, set up \\
\hline 1994 & -Keyboard rusak & -Ganti keyboard \\
\hline 1995 & $\begin{array}{l}\text {-Translate macet } \\
\text {-Gambar terbelah garis putih } \\
\text {-Uniformity jelek } \\
\text {-Komunikasi komputer PC/AT macet }\end{array}$ & $\begin{array}{l}\text {-Gear rompal/diganti } \\
\text {-ADC board rusak/diganti } \\
\text {-Balancing } \\
\text {-Digi-board rusak/diganti }\end{array}$ \\
\hline 1996 & $\begin{array}{l}\text {-Uniformity jelek } \\
\text {-Tidak bisa operasional }\end{array}$ & $\begin{array}{l}\text {-Kalibrasi flood } \\
\text {-Power supply rusak/kabel dimakan } \\
\text { tikus }\end{array}$ \\
\hline 1997 & $\begin{array}{l}\text {-Tidak berfungsi } \\
\text {-Gambar terpotong } \\
\text {-Gantry macet }\end{array}$ & $\begin{array}{l}\text {-Ganti Power Supply } \\
\text {-Memory DSP3000 diganti } \\
\text {-Ganti Board CPU }\end{array}$ \\
\hline 1998 & -Citra/image berlobang (hot-spot) & -1 bh PMT tube diganti \\
\hline 2000 & - CPU Computer PC/AT tak berfungsi & - Ganti Hardisk dan Set-up \\
\hline 2001 & - Uniformity jelek & - Lakukan Kalibrasi Flood \\
\hline 2002 & - Spektrum energi berubah & $\begin{array}{l}\text { - Bersihkan socket PMT dan HV } \\
\text { serta kalibrasi ulang. }\end{array}$ \\
\hline
\end{tabular}




\section{KESIMPULAN}

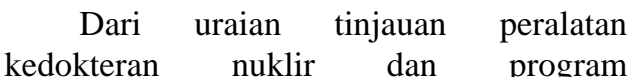
pemeliharaannya serta prospeknya untuk pengembangan kerjasama dengan mitra rumah sakit, dapat dikemukakan beberapa kesimpulan sbb :

1. Peralatan Kedokteran Nuklir terdiri dari berbagai instrumen yang kompleks, mulai

2. dari detektor nuklir, komponen elektronik yang sensitif dan sistem komputer lengkap, sehingga tugas perawatan harus mengenal berbagai sifat dan fungsi piranti tsb.

3. Kontrak perawatan Peralatan Kedokteran Nuklir relatif mahal, sementara life-cycle perkembangan teknologi peralatan sangat pendek, sehingga sering ditemui kesulitan dalam mendapatkan sukucadang pengganti (replaceparts) dan harganya menjadi mahal.

4. Program pemeliharaan peralatan bukanlah semata menyediakan dana dan kegiatan perbaikan, tetapi juga mencakup sampai kegiatan preventif serta pengkondisian laboratorium. Dalam keadaan keterbatas- an dana, upaya mempertahankan unjuk-kerja alat melalui pengelolaan perawatan preventif untuk memper- panjang life-time alat adalah merupakan kebijaksanaan yang tepat.

5. Dalam situasi ekonomi yang masih sulit dewasa ini, perlu digali dan dimanfaatkan kemampuan nasional dalam pemeliharaan peralatan kedokteran melalui pola kemitraan diantara Institusi terkait dan swasta adalah strategi yang tepat untuk optimasi peran rumahsakit (win-win). Hal ini sesungguhnya merupakan peluang dengan adanya kebijakan Pemerintah sekarang untuk memprioritaskan pemakaian produk dalam negeri.

6. Kegiatan pemeliharaan peralatan di rumah sakit memerlukan sistem manajemen yang efektif dan penyediaan tenaga ahli \& teknis yang terlatih. Karena kegiatan ini menyangkut penyediaan dana yang cukup banyak serta program pembinaan SDM yang kontinyu, maka diperlukan dukungan dari level Manajemen Rumah Sakit.

7. Program Quality Control test peralatan kedokteran nuklir perlu dilakukan agar gejala penyimpangan spesifikasi \& karakter alat terdeteksi lebih awal sehingga tindakan pencegahan terhadap kerusakan lebih besar dapat segera dilakukan.

8. Untuk peralatan yang sudah tua dan komponennya sudah pada tahap obsollete , dapat direkomendasikan untuk melakukan revitalization atau refurbishment dengan PC dan Software baru, atau jika sudah terlalu berat dapat dilakukan canibalism.

\section{UCAPAN TERIMA KASIH}

Penulis ingin menyampaikan ucapan terima kasih kepada Sdr. Yusuf staf BEM-P3TM yang telah membantu kami dalam memberikan data hasil perawatan Gamma Camera di rumah sakit.

\section{DAFTAR PUSTAKA}

1. IAEA Third Working Group Meeting on Regional Association of Gamma Camera Users, Kyoto, Japan , 30 September - 04 October, 1996.

2. Rill Isaris, "Pemeliharaan Instrumentasi Nuklir“, Prosiding Pertemuan dan Presentasi Ilmiah Pengetahuan Dasar Iptek Nuklir, Yogyakarta, 1994

3. IAEA Report "On Review Meeting of The Regional Non-RCA Project RAS/4/017 Maintenance and Repair of Nuclear Instruments”, Colombo Sri Lanka, June 2002.

4. Rill Isaris , "Survai dan pengendalian Mutu Peralatan Kedokteran Nuklir“, Pertemuan dan Presentasi Ilmiah Penelitian Dasar Iptek Nuklir, Yogyakarta, April 1992.

5. IAEA-TECDOC, "Safety Related Maintenance in the Framework of the Reliability Centered Maintenance Concept“, Vienna, Austria , 1992. 
6. Iyos R. Subki, "Nuclear Medicine in Indonesia : Present Reality and Prospect beyond 2000“, Proceeding of the Sixth Asia and Oceania Congress of Nuclear Medicine and Biology, Kyoto, Japan, 30 September - 6 October, 1996.

7. Fidler, Valentin., "Current Trends in Nuclear Instrumentation in Diagnostic Nuclear Medicine”, Jurnal Radio Oncology 2000; 34(4); 381-5, 2000.

8. IAEA-TECDOC 281, "Use and maintenance of Nuclear Medicine Instruments in Southeast Asia“, Vienna, Austria, 1983.

9. Rill Isaris, "Maintenance of Nuclear Instrument in Indonesia“, Country Report of RAS/4/008 Project, the Third Working Group Meeting on the Regional Association of Gamma Camera Users, Kyoto, Japan, October, 1996.
10. IAEA TECDOC- 317, "Quality Control of Nuclear Medicine Instruments", A Technical Document issued by the International Atomic Energy Agency, Vienna, 1984.

11. SMART, Richard, "The 1994 Survey of Gamma Camera and Quality Control in Australia“, Technical Standards Subcommittee of the ANZSNM and in association with the IAEA.

12. Rill Isaris, "Instrumentasi Nuklir dan Perannya dalam Diagnostik Kedokteran Nuklir“, Orasi Pengukuhan Ahli Peneliti Utama BATAN, LIPI, Jakarta, Oktober 2002.

13. "The Physisc of Medical Imaging“, edited by Steve Webb, Institute of Physics Publishing, Bristol and Philadelphia, 1998. 